\title{
Tele-Patch: Inevitable Consequence of the Pandemic
}

\section{(1) Ayșegül Satılmıș Kaya, (1) Esra Adıșen}

Gazi University Faculty of Medicine, Department of Dermatology, Ankara, Turkey

Keywords: Tele-patch, COVID-19, Patch test, Teledermatology, Case report

\section{Dear Editor,}

Telemedicine tools are viewed as essential and safe tools to improve the delivery of health services and become increasingly popular especially during the Coronavirus disease-2019 (COVID-19) pandemic. The principle aim of their use is to reduce and limit the number of face-to-face visits to hospitals thereby prevent the spread of the virus. Allowing quarantined COVID-19 patients to be given dermatologic consultation points to another benefit of the telemedicine applications [1]. Although the use of teledermatology for patch testing is not a new entity, it is limited to consultation of the photographs of patients whose patch tests are photographed in clinics to dermatologists by Store-and-Forward technology [2]. Herein we present a patient whose patch test was evaluated via teledermatology method because he was quarantined due to COVID-19 on the day of the patch test.

A 45-year-old male patient applied to the outpatient clinic with contact dermatitis in the hands. Since the patient's complaints responded partially to topical corticosteroid, a patch test was planned at the control examination. The patch test with a standard series of 30 allergens was applied to the patient's back, and the patient was called back to the hospital for the $48^{\text {th }}$ and $72^{\text {nd }}$-hour test readings. The patient was quarantined due to the diagnosis of COVID-19 in his mother and sibling on the day of the patch test, so the $48^{\text {th }}$ (Figure 1) and $72^{\text {nd }}$ (Figure $2 \mathrm{~A}$ ) test results of the patient was evaluated through the photographs sent by the patient using the mobile phone. The patch test result of the patient was evaluated as a $2+$ reaction with potassium dichromate $0.5 \%$ (Figure
2B) and cobalt chloride hexahydrate 1.0\% (Figure 2C), and detailed information about the allergens was sent to the patient via e-mail.

Although the combination of vision and palpating the induration is necessary for evaluating the results of the patch test, in a study in which the patch test results of the patients were evaluated only with photographs, only 6\% failure was detected [3]. Spanish Contact

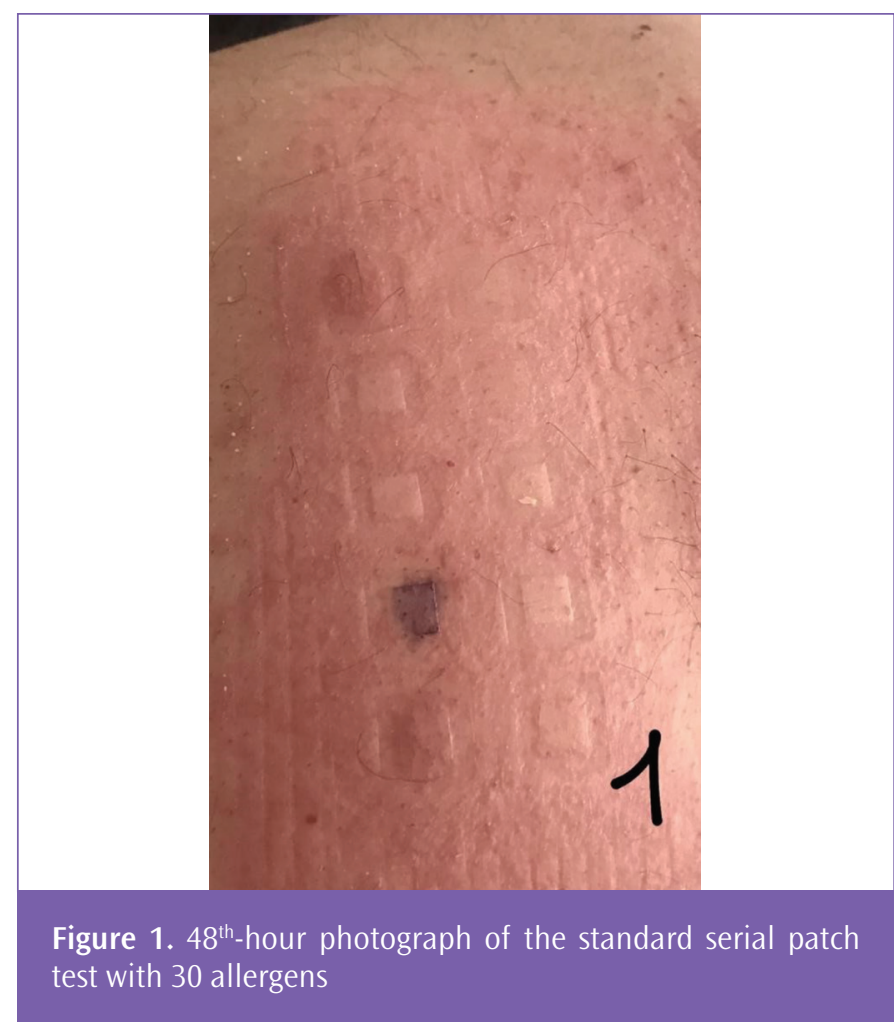




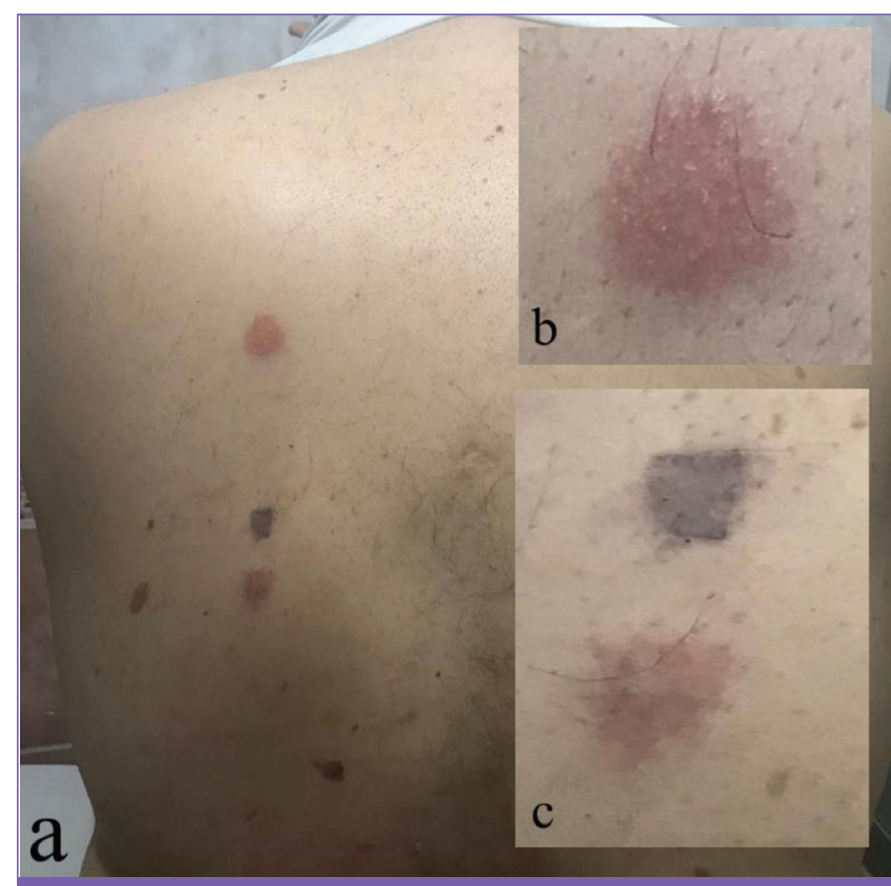

Figure 2. A) $72^{\text {nd }}$-hour photograph of the patch test with 30 allergens, close view of $2+$ reaction with potassium dichromate $0.5 \%$ (B) and cobalt chloride hexahydrate $1.0 \%$ (C)

Dermatitis and Skin Allergy Research Group has proposed that patch test reading can be done in COVID-19 pandemic on photographs sent by patients in exceptional circumstances [3]. The virtual evaluation of patch test results is easy if there is negativity in the whole series, but weak positivity and irritant reactions can be confusing sometimes for dermatologists. Due to the image quality of the photographs is not always perfect, and difficulty for assessment without palpation of erythema, subtle edema, and vesiculation, virtual evaluation of photographs submitted by patients seems difficult to replace faceto-face evaluation. On the other hand, in exceptional cases, such as our patient, the patient's patch test can be read with a Store-andForward teledermatology using technological tools.

\section{Ethics}

Informed Consent: Consent form was filled out by all participants.

Peer-review: Internally peer-reviewed.

\section{Authorship Contributions}

Concept: A.S.K., Design: E.A., Data Collection or Processing: E.A., Analysis or Interpretation: A.S.K., Literature Search: A.S.K., Writing: A.S.K.

Conflict of Interest: No conflict of interest was declared by the authors.

Financial Disclosure: The authors declared that this study received no financial support.

\section{References}

1. Elsner P. Teledermatology in the times of COVID-19 - a systematic review. J Dtsch Dermatol Ges 2020;18:841-845.

2. Grey KR, Hagen SL, Hylwa SA, Warshaw EM. Utility of Store and Forward Teledermatology for Skin Patch Test Readings. Dermatitis 2017;28:152-161.

3. Carrascosa JM, Pastor-Nieto MA, Ruiz-González I, Silvestre JF, Borrego L, Gatica-Ortega ME, Giménez-Arnau AM; en representación del Grupo Español de Investigación en Dermatitis de Contacto y Alergia Cutánea (GEIDAC); Miembros del Grupo Español de Investigación en Dermatitis de Contacto y Alergia Cutánea (GEIDAC). Patch Testing During the COVID-19 Pandemic: Recommendations of the AEDV's Spanish Contact Dermatitis and Skin Allergy Research Group (GEIDAC). Actas Dermosifiliogr (Engl Ed) 2020;111:650-654. 